\title{
Connexinplexity: The spatial and temporal expression of connexin genes during vertebrate organogenesis
}

\author{
Rachel M. Lukowicz-Bedford, Dylan R. Farnsworth, Adam C. Miller \\ Institute of Neuroscience, University of Oregon, Eugene, OR \\ Correspondence: acmiller@uoregon.edu
}

\begin{abstract}
Animal development requires coordinated communication between cells. The Connexin family of proteins is a major contributor to intercellular communication in vertebrates by forming gap junction channels that facilitate the movement of ions, small molecules, and metabolites between cells. Additionally, individual hemichannels can provide a conduit to the extracellular space for paracrine and autocrine signaling. Connexin-mediated communication is well appreciated in epithelial, neural, and vascular development and homeostasis, and most tissues likely use this form of communication. In fact, Connexin disruptions are of major clinical significance contributing to disorders developing from all major germ layers. Despite the fact that Connexins serve as an essential mode of cellular communication, the temporal and celltype specific expression patterns of connexin genes remain unknown in vertebrates. A major challenge is the large and complex connexin gene family. To overcome this barrier, we probed the expression of all connexins in zebrafish using single-cell RNA-sequencing of entire animals across several stages of organogenesis. Our analysis of expression patterns has revealed that few connexins are broadly expressed, but rather, most are expressed in tissue- or cell-typespecific patterns. Additionally, most tissues possess a unique combinatorial signature of connexin expression with dynamic temporal changes across the organism, tissue, and cell. Our analysis has identified new patterns for well-known connexins and assigned spatial and temporal expression to genes with no-existing information. We provide a field guide relating zebrafish and human connexin genes as a critical step towards understanding how Connexins contribute to cellular communication and development throughout vertebrate organogenesis.
\end{abstract}




\section{Introduction}

Animal development and homeostasis requires coordinated cellular communication. One method mediating communication are gap junction (GJ) channels. GJs are intercellular channels that provide a direct path of low resistance for ionic and small molecule exchange between cells ${ }^{1}$. These channels are formed by the coupling of two apposed hemi-channels each contributed by adjacent communicating cells ${ }^{1-3}$. Additionally, hemi-channels can work independently within a single cell's membrane, where they can release small molecules such as ATP and glutamate into the extracellular space for paracrine and autocrine signaling ${ }^{2,3}$. The proteins that create GJ channels are evolutionarily unrelated in vertebrates and invertebrates ${ }^{4}$. Yet despite little sequence similarity ${ }^{5}$, the vertebrate Connexins and the invertebrate Innexin proteins have similar structure, with both classes creating four-pass, transmembrane-domain proteins that oligomerize to form each hemichannel within the plasma membrane ${ }^{4}$. Moreover, the hemi-channels and intercellular GJs created by Connexins and Innexins have similar structure and function ${ }^{4}$. Outside of these traditional roles, Connexins can also modulate the formation of tunneling nanotubes, that connect non-adjacent cells to facilitate longer distance communication $^{6-8}$. These varied functions in cellular communication are likely utilized individually and in combination in all animal tissues ${ }^{9}$, yet are best studied in epithelial ${ }^{10}$, neural ${ }^{11}$, and vascular ${ }^{12}$ systems. In these systems, mutations in human Connexin-encoding genes have been linked to defects in the development, regulation, and function including skin disorders ${ }^{13-16}$, cataracts $^{17,18}$, deafness ${ }^{19-21}$, cardiovascular disease ${ }^{22-24}$, and gastrointestinal diseases ${ }^{25-27}$. While Connexin channels serve as an essential form of cellular communication, the temporal and cell-type specific expression patterns of connexin genes largely remain unknown.

A major challenge in characterizing connexin expression is the complexity of the gene family. In humans, there are 20 distinct connexin genes, and in other vertebrate lineages the number of Connexin-encoding genes is similarly large and varies widely ${ }^{28-30}$. Cell culture and in vitro work suggests that connexin complexity provides functional diversity governed by four general principles: first, hemichannels are created by hexamers of individual Connexin proteins $^{31}$; second, single or multiple Connexin proteins can contribute to hemichannel formation (homo- or heteromeric hemichannels, respectively) ${ }^{32-34}$; third, gap junctions form intercellular channels via hemichannel docking at cell-cell junctions; fourth, each contributed hemichannel can contain the same or different Connexin proteins (homo- or heterotypic channels, respectively $)^{32-34}$. The combinatorial possibilities of the gene family are restrained by molecular engagement rules that limit which Connexins are compatible to form mixed channels ${ }^{34-37}$. These diverse possibilities culminate in each hemichannel having its own unique permeability 
properties, dependent upon the pore-lining amino acids and channel gating properties of the individual Connexins ${ }^{37,38}$. These rules suggest animals might take advantage of Connexinbased complexity in vivo to generate unique functional outcomes, but given the large number of genes, we know little about how vertebrates deploy this gene family.

Most of our knowledge of connexin expression in vivo comes from only a handful of wellcharacterized genes. These examples support the idea that connexins can be expressed in distinct tissues, such as in mouse where gap junction a1/Connexin 43 (Gja1/CX43) is expressed extensively in non-neuronal cells, including epithelia ${ }^{39}$, heart ${ }^{24,40}$, and glia $^{41}$. By contrast, Gjd2/CX36 is found almost exclusively in neurons ${ }^{42}$. Within the same tissue, connexin expression can have distinct temporal patterns, such as Gjb2/CX26 and Gjb1/CX32 that are both found in the developing mouse neocortex at distinct developmental time points ${ }^{43}$. Within the group of well-studied Connexins, there are also a few enticing examples that suggest the rules of Connexin functional complexity found in vitro are relevant to in vivo function. For example, heteromeric channels formed by Gjb1/CX32 and Gjb2/CX26 are found in the mammary gland and the composition of channels changed during development ${ }^{44}$. Heterotypic gap junctions composed of gjd2a/Cx35.5 and gjd1a/Cx34.1 are found at electrical synapses of zebrafish Mauthner cells where each Connexin was required for the localization of the other in the adjacent cell and both were necessary for synaptic transmission ${ }^{45,46}$. Finally, replacing the coding region of Gja1/CX43 with either Gja5/CX40 or Gjb1/CX32 results in sterility, cardiac malformations and arrhythmias, and mothers unable to nourish their pups, suggesting that each Connexin has unique properties that contribute to cellular homeostasis that cannot be simply interchangeable with other Connexins ${ }^{47}$. While these examples provide a glimpse of functional complexity, understanding the expression of this gene family through vertebrate development remains as the critical first step to decoding the complexity of connexin usage in vivo.

Here we set out to examine the expression of all connexins in a vertebrate model system, the developing zebrafish, using single-cell RNA-sequencing (scRNA-seq) of cells derived from the entire animal during organogenesis (1-5 days post-fertilization (dpf) $)^{48}$. Our analysis of connexin expression patterns revealed several trends, including that few connexins are broadly expressed, but rather, most connexins are spatially restricted to tissue- or cell-typespecific expression patterns. Most cells contain combinatorial signatures of connexins with unique profiles within distinct tissues. Finally, connexin expression is dynamic with temporal changes across the organism, tissue, and cell type. Our results reveal the complexity of spatiotemporal connexin control, highlighting novel aspects of well-studied connexins and revealing patterns for connexin genes with no prior expression information. We provide a field guide to 
relate zebrafish and human connexins genes, based on evolutionary homologies and expression similarities. Collectively, this represents an important step towards understanding connexin gene contributions in cellular communication throughout organogenesis and provides a foundation for comparative analysis in vertebrates.

\section{Results}

Zebrafish have 41 connexin genes

To understand connexin expression throughout organogenesis we first set out to ensure the entire connexin gene family in zebrafish was identified. Previous efforts ${ }^{28,49}$ and a recent phylogenetic approach to identify the full teleost connexin family ${ }^{30}$ captured 40 individual connexin genes. Through reciprocal BLAST analysis between the zebrafish genome and (1) human and (2) other teleost Connexin sequences, coupled with phylogenetic analysis, we identified the 40 previously noted connexins and one previously unreported connexin, gjz1, which is conserved in mammals but forms an outgroup with the rest of the Connexin proteins (Supp Fig. 1, 2).

Across the family of connexin genes there are seven human connexins for which zebrafish only has a single homolog, eight human connexins for which zebrafish has two homologs, two zebrafish connexins that have no direct homolog but share sequence similarity to human connexins, and sixteen zebrafish connexins that are not present in humans but are conserved in other teleost and mammalian lineages ${ }^{30}$. We summarize these relationships in Table 1, listing zebrafish connexin genes and their closest relationship with their human counterparts, providing known human and zebrafish expression patterns and phenotypes for comparison. For clarity, we denote connexins by their Greek name and by their predicted molecular weight, a naming structure consistent with HUGO $^{50}$ and ZFIN standards ${ }^{51}$ (Table 1, Supp. Table 1). The table is organized to emphasize Connexin similarities based on evolutionary homology, protein sequence, and expression, in alphabetical order of zebrafish connexin genes and denotes human similarity across merged rows. There are a limited number of rows where the zebrafish connexin gene resembles its human counterpart(s), but the genes are not direct homologs. For example, the human GJB2/GJB6 genes are duplicated in the human lineage while having only a single similar gene in zebrafish called $g j b 8^{30}$. Despite not being direct homologs, expression and mutant analyses have found that zebrafish gjb8 and human GJB2/GJB6 genes are all involved in inner-ear support cell function and loss of these genes in their respective systems causes deafness ${ }^{20,52,53}$. The comprehensive list of 41 
zebrafish connexin genes provided a basis to examine the expression patterns of this gene family.

Table 1. A field guide to zebrafish connexins.

\begin{tabular}{|c|c|c|c|c|}
\hline $\begin{array}{l}\text { Zebrafish } \\
\text { Connexin } \\
\text { gene/protein }\end{array}$ & $\begin{array}{l}\text { Phenotypes } \\
\text { associated with } \\
\text { zebrafish } \\
\text { Connexin } \\
\text { gene/protein }\end{array}$ & $\begin{array}{l}\text { Updated } \\
\text { scRNA-seq } \\
\text { tissue/cluster }\end{array}$ & $\begin{array}{l}\text { Human } \\
\text { Connexin } \\
\text { gene/protein }\end{array}$ & $\begin{array}{l}\text { Diseases } \\
\text { associated with } \\
\text { human Connexin } \\
\text { gene/protein }\end{array}$ \\
\hline gja1a/Cx40.8 & $\begin{array}{l}\text { no known } \\
\text { phenotype }\end{array}$ & $\begin{array}{l}\text { Neural crest, } \\
\text { connective } \\
\text { tissue, nervous } \\
\text { system }\end{array}$ & \multirow[t]{2}{*}{ GJA1/CX43 } & \multirow[t]{2}{*}{$\begin{array}{l}\text { Bone, skin, eye, } \\
\text { teeth, heart, and } \\
\text { digit } \\
\text { abnormalities }^{54-58}\end{array}$} \\
\hline gja1b/Cx43 & $\begin{array}{l}\text { Smaller body } \\
\text { shape and } \\
\text { shortened fins } \\
\text { sho,60, } \\
\text { disrupted } \\
\text { regertebrae } \\
\text { regeneration }^{62}, \text { and } \\
\text { diminished motile } \\
\text { cilia }^{63}\end{array}$ & $\begin{array}{l}\text { Broadly } \\
\text { expressed }\end{array}$ & & \\
\hline gja2/Cx39.9 & $\begin{array}{l}\text { Decreased skeletal } \\
\text { slow muscle } \\
\text { contractability }^{64}\end{array}$ & $\begin{array}{l}\text { Skeletal } \\
\text { Muscle }\end{array}$ & - & - \\
\hline gja3/Cx46 & $\begin{array}{l}\text { Heart } \\
\text { abnormalities }^{65,66}\end{array}$ & Lens, heart & GJA3/CX46 & Cataracts $^{67-70}$ \\
\hline gja4/Cx39.4 & $\begin{array}{l}\text { Disrupted pigment } \\
\text { patterns }^{71}\end{array}$ & $\begin{array}{l}\text { Endothelial, } \\
\text { pigment cells }\end{array}$ & GJA4/CX37 & $\begin{array}{l}\text { Cardiovascular } \\
\text { abnormalities }^{23}\end{array}$ \\
\hline gja5a/Cx45.6 & $\begin{array}{l}\text { Faster vessel } \\
\text { growth }^{72}\end{array}$ & $\begin{array}{l}\text { Muscle, } \\
\text { endothelial }\end{array}$ & \multirow[t]{2}{*}{ GJA5/CX40 } & \multirow{2}{*}{$\begin{array}{l}\text { Cardiovascular } \\
\text { abnormalities } \\
76\end{array}$} \\
\hline gja5b/Cx41.8 & $\begin{array}{l}\text { Leopard pigment } \\
\text { patterns }{ }^{49,60,71,77}, \\
\text { faster vessel } \\
\text { growth }^{72}\end{array}$ & $\begin{array}{l}\text { Pigment cells, } \\
\text { endothelial }\end{array}$ & & \\
\hline - & - & & $\begin{array}{l}\text { GJA6P/CX43 } \\
\mathrm{px}\end{array}$ & - \\
\hline gja8a/Cx79.8 & $\begin{array}{l}\text { no known } \\
\text { phenotype }\end{array}$ & Lens & \multirow[t]{2}{*}{ GJA8/CX50 } & \multirow[t]{2}{*}{ Cataracts $^{17,78-80}$} \\
\hline gja8b/Cx44.1 & Cataracts $^{81}$ & Lens & & \\
\hline gja9a/Cx55.5 & $\begin{array}{l}\text { Disrupted } \\
\text { perception of light } \\
\text { stimulation }^{82}\end{array}$ & $\begin{array}{l}\text { Nervous } \\
\text { system, } \\
\text { integument }\end{array}$ & \multirow[t]{2}{*}{ GJA9/CX58 } & \multirow[t]{2}{*}{$\begin{array}{l}\text { no known } \\
\text { implications }\end{array}$} \\
\hline gja9b/Cx52.9 & $\begin{array}{l}\text { no known } \\
\text { phenotype }\end{array}$ & Retina & & \\
\hline gja10a/Cx52.7 & $\begin{array}{l}\text { no known } \\
\text { phenotype }\end{array}$ & $\begin{array}{l}\text { low expression } \\
\text { in this dataset }\end{array}$ & \multirow[t]{2}{*}{ GJA10/CX62 } & \multirow[t]{2}{*}{$\begin{array}{l}\text { no known } \\
\text { implications }\end{array}$} \\
\hline gja10b/Cx52.6 & $\begin{array}{l}\text { no known } \\
\text { phenotype }\end{array}$ & Retina & & \\
\hline
\end{tabular}




\begin{tabular}{|c|c|c|c|c|}
\hline gja11/Cx34.5 & $\begin{array}{l}\text { no known } \\
\text { phenotype }\end{array}$ & $\begin{array}{l}\text { low expression } \\
\text { in this dataset }\end{array}$ & - & - \\
\hline gja12.1/Cx28.9 & $\begin{array}{l}\text { no known } \\
\text { phenotype }\end{array}$ & $\begin{array}{l}\text { Liver, intestine, } \\
\text { kidney }\end{array}$ & - & - \\
\hline $\begin{array}{l}\text { gja12.2/ } \\
\text { Cx28.1 }\end{array}$ & $\begin{array}{l}\text { no known } \\
\text { phenotype }\end{array}$ & Intestine & - & - \\
\hline $\begin{array}{l}\text { gja13.1/ } \\
\text { Cx32.3 }\end{array}$ & $\begin{array}{l}\text { no known } \\
\text { phenotype }\end{array}$ & $\begin{array}{l}\text { Liver, intestine, } \\
\text { kidney }\end{array}$ & - & - \\
\hline gja13.2/C $\times 32.2$ & $\begin{array}{l}\text { no known } \\
\text { phenotype }\end{array}$ & Macrophage & - & - \\
\hline gjb1a/Cx27.5 & $\begin{array}{l}\text { no known } \\
\text { phenotype }\end{array}$ & Schwann Cell & \multirow[t]{2}{*}{ GJB1/CX32 } & \multirow{2}{*}{$\begin{array}{l}\text { Neuropathy }(X- \\
\text { linked Charcot- } \\
\text { Marie-Tooth })^{83,84}\end{array}$} \\
\hline gjb1b/Cx31.7 & $\begin{array}{l}\text { Disrupted spacing } \\
\text { of muller glia cells }\end{array}$ & Schwann Cell & & \\
\hline gjb3/Cx35.4 & $\begin{array}{l}\text { no known } \\
\text { phenotype }\end{array}$ & Integument & GJB3/CX31 & $\begin{array}{l}\text { Deafness }{ }^{21,86}, \text { Skin } \\
\text { abnormalities }\end{array}$ \\
\hline gjb7/Cx28.8 & $\begin{array}{l}\text { no known } \\
\text { phenotype }\end{array}$ & $\begin{array}{l}\text { Integument, } \\
\text { hair cell, } \\
\text { olfactory } \\
\text { neurons }\end{array}$ & GJB7/CX25 & $\begin{array}{l}\text { no known } \\
\text { implications }\end{array}$ \\
\hline \multirow[t]{2}{*}{ gjb8/Cx30.3 } & \multirow[t]{2}{*}{$\begin{array}{l}\text { Disrupted inner ear } \\
\text { development }^{53}\end{array}$} & \multirow{2}{*}{$\begin{array}{l}\text { Integument, } \\
\text { pigment cell, } \\
\text { endothelial, } \\
\text { hair cell }\end{array}$} & GJB2/CX26 & $\begin{array}{l}\text { Deafness }{ }^{19,87}, \text { Skin } \\
\text { abnormalities }\end{array}$ \\
\hline & & & GJB6/CX30 & $\begin{array}{l}\text { Deafness }{ }^{20,89}, \text { Skin } \\
\text { abnormalities }\end{array}$ \\
\hline gjb9a/Cx28.6 & $\begin{array}{l}\text { no known } \\
\text { phenotype }\end{array}$ & Integument & \multirow[t]{2}{*}{-} & \multirow[t]{2}{*}{-} \\
\hline gjb9b/Cx30.9 & $\begin{array}{l}\text { no known } \\
\text { phenotype }\end{array}$ & $\begin{array}{l}\text { Integument, } \\
\text { macrophage }\end{array}$ & & \\
\hline \multirow[t]{2}{*}{ gjb10/Cx34.4 } & \multirow[t]{2}{*}{$\begin{array}{l}\text { Impaired cardiac } \\
\text { function }^{91}\end{array}$} & \multirow{2}{*}{$\begin{array}{l}\text { Integument, } \\
\text { neural crest, } \\
\text { nervous } \\
\text { system }\end{array}$} & GJB4/CX30.3 & $\begin{array}{l}\text { Skin } \\
\text { abnormalities }{ }^{13,92}\end{array}$ \\
\hline & & & GJB5/CX31.1 & $\begin{array}{l}\text { no known } \\
\text { implications }\end{array}$ \\
\hline gjc1/Cx52.8 & $\begin{array}{l}\text { no known } \\
\text { phenotype }\end{array}$ & $\begin{array}{l}\text { Muscle, neural } \\
\text { crest, nervous } \\
\text { system }\end{array}$ & GJC1/CX45 & $\begin{array}{l}\text { no known } \\
\text { implications }\end{array}$ \\
\hline gjc2/Cx47.1 & $\begin{array}{l}\text { no known } \\
\text { phenotype }\end{array}$ & Schwann Cell & GJC2/CX47 & $\begin{array}{l}\text { Myelin } \\
\text { disorders } \\
\text { Lymphatic }^{93,94} \text {, } \\
\text { abnormalities }^{95}\end{array}$ \\
\hline- & - & - & GJC3/CX29 & $\begin{array}{l}\text { no known } \\
\text { implications }\end{array}$ \\
\hline gjc4a.1/Cx44.2 & $\begin{array}{l}\text { no known } \\
\text { phenotype }\end{array}$ & $\begin{array}{l}\text { Vasculature, } \\
\text { integument }\end{array}$ & \multirow[t]{3}{*}{-} & \multirow[t]{3}{*}{-} \\
\hline gjc4a.2/Cx44.5 & $\begin{array}{l}\text { no known } \\
\text { phenotype }\end{array}$ & Integument & & \\
\hline gjc4b/Cx43.4 & $\begin{array}{l}\text { Disrupted left/right } \\
\text { symmetry and } \\
\text { abnormal kupffer's } \\
\text { vesicle } \\
\text { development }^{96}\end{array}$ & $\begin{array}{l}\text { Broadly } \\
\text { expressed }\end{array}$ & & \\
\hline
\end{tabular}




\begin{tabular}{|c|c|c|c|c|}
\hline gjd1a/Cx34.1 & $\begin{array}{l}\text { Loss of electrical } \\
\text { synapses, } \\
\text { disrupted startle } \\
\text { response }^{45}\end{array}$ & $\begin{array}{l}\text { Nervous } \\
\text { system, retina }\end{array}$ & GJD2/CX36 & $\begin{array}{l}\text { Epilepsy } \\
\text { associated }^{97}\end{array}$ \\
\hline gjd1b/Cx34.7 & & $\begin{array}{l}\text { Nervous } \\
\text { system, retina, } \\
\text { muscle }\end{array}$ & & \\
\hline gjd2a/Cx35.5 & $\begin{array}{l}\text { Myopia, loss of } \\
\text { electrical synapses, } \\
\text { disrupted startle } \\
\text { response }^{45,98}\end{array}$ & $\begin{array}{l}\text { Nervous } \\
\text { system, retina }\end{array}$ & & \\
\hline gjd2b/Cx35.1 & Myopia $^{98}$ & $\begin{array}{l}\text { Nervous } \\
\text { system, retina }\end{array}$ & & \\
\hline- & - & - & GJD3/CX31.9 & $\begin{array}{l}\text { no known } \\
\text { implications }\end{array}$ \\
\hline gjd4/Cx46.8 & $\begin{array}{l}\text { no known } \\
\text { phenotype }\end{array}$ & $\begin{array}{l}\text { Skeletal } \\
\text { muscle }\end{array}$ & GJD4/CX40.1 & $\begin{array}{l}\text { no known } \\
\text { implications }\end{array}$ \\
\hline gjd5/Cx40.5 & $\begin{array}{l}\text { no known } \\
\text { phenotype }\end{array}$ & $\begin{array}{l}\text { low expression } \\
\text { in this dataset }\end{array}$ & - & - \\
\hline gjd6/Cx36.7 & $\begin{array}{l}\text { Abnormal cardiac } \\
\text { muscle tissue } \\
\text { development }^{99}\end{array}$ & Heart & - & - \\
\hline gje1a/Cx23.9 & $\begin{array}{l}\text { no known } \\
\text { phenotype }\end{array}$ & Lens & \multirow[t]{2}{*}{ GJE1/CX23 } & \multirow[t]{2}{*}{$\begin{array}{l}\text { no known } \\
\text { implications }\end{array}$} \\
\hline gje $1 \mathrm{~b} / \mathrm{C} \times 20.3$ & $\begin{array}{l}\text { no known } \\
\text { phenotype }\end{array}$ & $\begin{array}{l}\text { Skeletal } \\
\text { muscle, } \\
\text { nervous } \\
\text { system }\end{array}$ & & \\
\hline gjz1/Cx26.3 & $\begin{array}{l}\text { no known } \\
\text { phenotype }\end{array}$ & $\begin{array}{l}\text { Nervous } \\
\text { system }\end{array}$ & - & - \\
\hline
\end{tabular}

The connexin gene family is broadly expressed, but spatially distinct

Next, we examined the spatio-temporal expression patterns of the zebrafish connexin genes through organogenesis using scRNA-seq. We used our recent scRNA-seq atlas dataset in which cells were dissociated from whole embryos at 1, 2, and 5 days post fertilization (dpf), and resultant single-cell expression profiles were captured using the $10 \mathrm{X}$ platform ${ }^{48}$. In our initial analysis of the data, we found that many of the connexin genes lacked expression information. An examination of the connexin gene models generated by Ensembl (GRCz11_93) that were used for mapping single cell reads revealed that most annotations were truncated at or near the end of the protein coding sequence, with most lacking 3'UTRs leading to a failure in capturing the 3'-biased 10X sequencing information (Supp. Fig. 3). To amend this, we used a recently updated gene annotation file that extends gene models ${ }^{100}$, evaluated and updated each connexin gene model in reference to bulk RNA-seq data ${ }^{101}$, and imported the Greek gene 


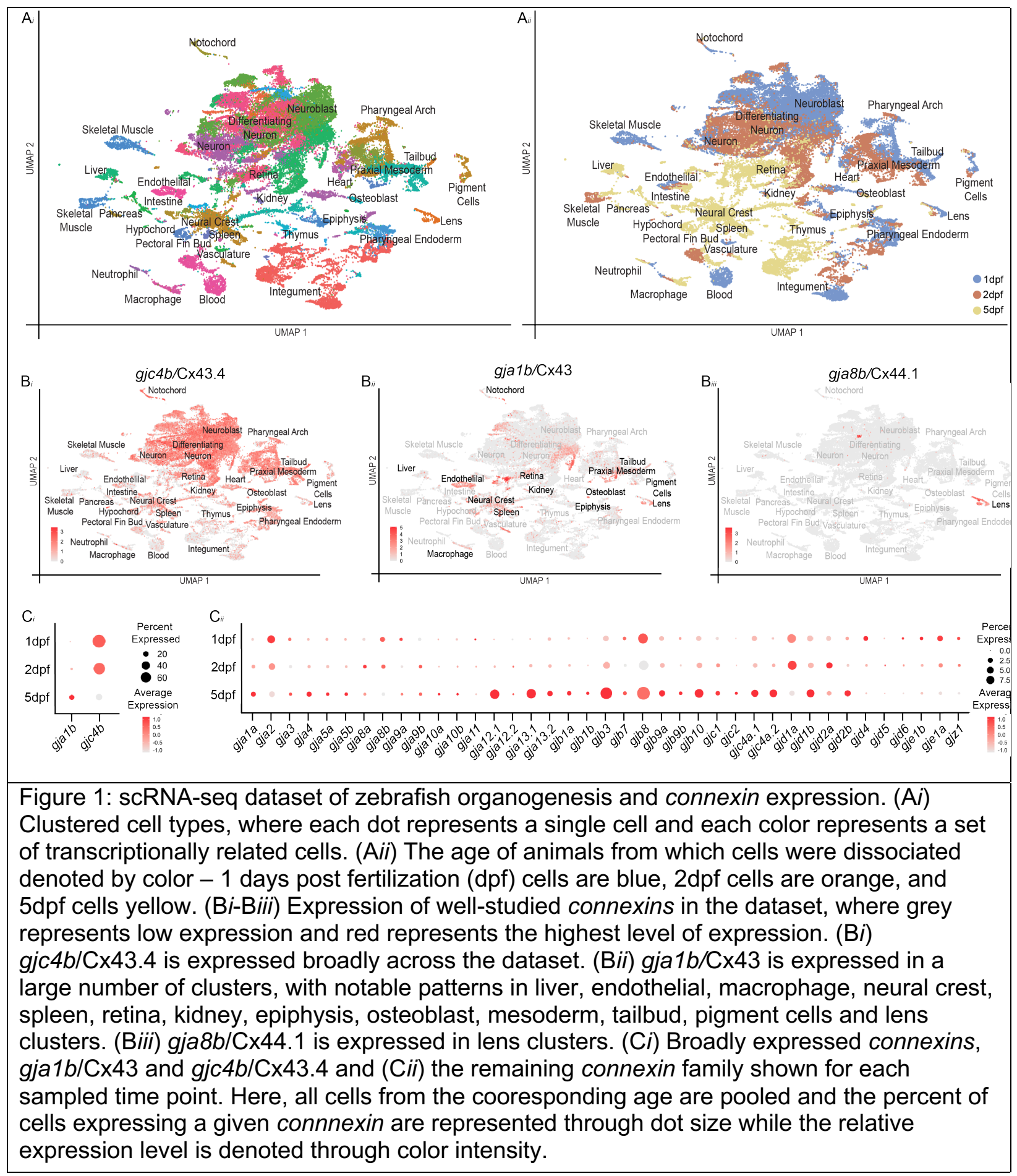

names. Using this updated gene annotation file, we processed the scRNA-seq data using Cellranger ${ }^{102}$ and evaluated clustering and transcriptional profiles with Seurat ${ }^{103}$. Analysis of the updated scRNA-seq dataset captures transcriptional profiles that appear to represent all major tissues of the developing zebrafish (Fig. 1Ai, Aii) and contains 49,367 cells and 238 clusters. 
This is 5,355 more cells and 18 more clusters than the original analysis ${ }^{48}$, as expected due to the richer transcriptional information captured from the updated gene model ${ }^{100}$. In our original analysis, we extensively annotated each cluster, assigning the most likely anatomical annotation based on comparing the differentially expressed genes for each cluster to RNA in situ patterns ${ }^{48}$. We transferred these previous annotations to our updated analysis by identifying cell-specific barcodes from the original dataset, identifying them in the updated clusters, and transferring the cluster annotations (Fig. 1Ai, Aii; Supp. Table 1,2). As a result, we identified all 220 original clusters ${ }^{48}$ and annotated the remaining clusters by analyzing RNA in situ expression information for the most differentially expressed genes (Supp. Table 3). The updated scRNA-seq dataset greatly improves the capture of connexin expression throughout the atlas (Supp. Fig. 3), allowing us to examine their spatio-temporal expression pattern during zebrafish organogenesis.

Using the updated scRNA-seq organogenesis dataset, we examined the expression of each connexin related to its clusters, its correlation with marker gene expression, and with cluster annotations (Supp. Fig. 4A-OO, Supp. Table 4). Overall, connexin genes had a variety of expression patterns, varying from nearly ubiquitous to cluster-specific and showing a variety of temporal profiles, including constant expression over time or temporal specificity (Fig. 1B,C, Supp. Fig.4 A-OO). To begin to evaluate the dataset's utility, we first turned our attention to several well-studied connexin genes. First, gjc4b/Cx43.4 displayed the broadest expression, with particularly high levels in the nervous system, and with diminishing expression from 1 to 5 dpf (Fig. 1Bi,Ci; Supp. Fig. 5; Supp. Table 4). This is similar to expression reports for gjc4b/Cx43.4 that used RNA in situ and transgenic methods ${ }^{104-106} \cdot$ gja1b/Cx43 is another welldescribed connexin, with broad expression in the cardiovascular system, non-neuronal cells of the retina and central nervous system, mesenchymal cells such as chondrocytes, and within the digestive system including the pancreas ${ }^{62,107-110}$. We find that expression of gja1b/Cx43 within the updated clusters largely matches these reported expression patterns (Fig.1 Bii; Supp. Fig.4B; Supp. Table 4). We also find expected patterns for connexins that have well-known, spatially-restricted expression. For example, gja8b/Cx44.1 is expressed almost exclusively in the early developing lens ${ }^{111-114}$, and in the scRNA-seq dataset we find expression of gja8b/Cx44.1 within clusters with transcriptional profiles consistent with lens cells (Fig. 1Biii; Supp. Figure 5; Supp. Table 4). Further, we find gja2/Cx39.9 expression in presumptive skeletal muscle cells, gjd6/Cx36.7 specifically in presumptive cardiac muscle, and both gja9b/Cx52.9 and gja10b/Cx52.6 in presumptive horizontal cells, all well-matching published reports on the expression of these genes ${ }^{64,99,111,114,115}$ (Supp. Figure 5; Supp. Table 4). Taken together, we 
bioRxiv preprint doi: https://doi.org/10.1101/2021.11.19.469275; this version posted November 20,2021 . The copyright holder for this preprint (which was not certified by peer review) is the author/funder, who has granted bioRxiv a license to display the preprint in perpetuity. It is made available under aCC-BY-NC 4.0 International license.

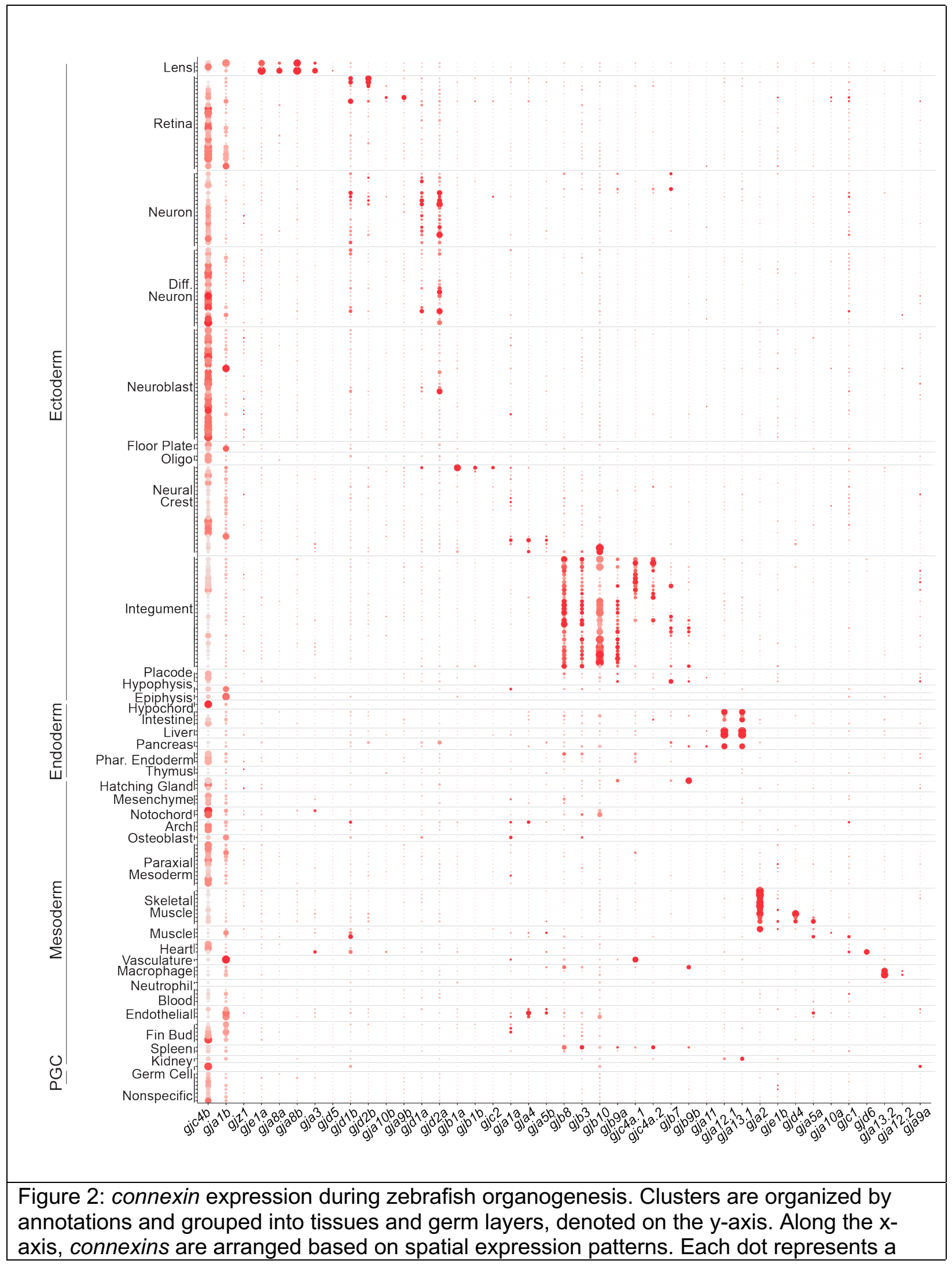


single cluster. The percent of cells expressing a given connnexin are represented through dot size while the relative expression level is denoted through color intensity. Diff. Neuron = Differentiating Neuron, Oligo = Oligodendrocyte, Phar. Endoderm $=$ Pharyngeal Endoderm, Arch $=$ Pharyngeal Arch, PGC $=$ Primordial Germ Cell

conclude that the data represented in the updated dataset provides a useful resource for determining the spatio-temporal patterns of connexin expression during zebrafish organogenesis.

connexins exhibit complex and combinatorial patterns of expression

To examine the relationship of connexin gene expression relative to one another, we organized the scRNA-seq clusters by their tissue annotations and plotted both expression levels and percentage of cells within each cluster (Fig. 2). When arranged in this fashion, the complexity of connexin expression within putative tissues and cell types is revealed. In particular, unique combinatorial patterns of connexins are observed within tissues developing from all germ layers. For example, within neural clusters (ectoderm), we find that there are four broadly expressed connexins, yet each displays bias to either the retina, gjd $1 \mathrm{~b} / \mathrm{Cx} 34.7$ and gjd2b/Cx35.1, or central nervous system, gjd1a/Cx34.1 and gjd2a/Cx35.5 (Fig. 2; Supp. Figure 4 AF-Al; Supp. Table 4). Within the the skeletal muscle clusters (mesoderm), a unique set of connexins are expressed and display a nested hierarchy of expression, with gja2/Cx39.9 in all skeletal muscle clusters, gja5a/Cx45.6 and gjd4/Cx46.8 are restricted to slow muscle clusters, and gje $1 \mathrm{~b} / \mathrm{Cx} 20.3$ is restricted to fast muscle clusters (Fig. 2; Supp Fig. 4C, JJ, F, NN). We also observed temporally complex patterns of expression. For example, within presumptive intestinal epithelial cells (endoderm), we find that gjc4b/Cx43.4 expression diminishes from 1 to $5 \mathrm{dpf}$, while gja13.1/Cx32.3 begins expression at $2 \mathrm{dpf}$ and continues at $5 \mathrm{dpf}$ and gja12.1/Cx28.9 becomes co-expressed at $5 \mathrm{dpf}$ (Fig. 2; Supp. Fig. 4Q, O, Supp. Fig. 6). Finally, we observed that primordial germ cells (PGC) express several different connexins, including gja9a/Cx55.5, gjb8/Cx30.3, gjc4b/Cx43.4, and gjd1b/Cx34.7 (Fig. 2; Supp. Figure 4W, J, GG, EE, Supp. Fig. 7). These observations highlight aspects of the complexity of connexin spatial and temporal expression patterns within and across tissues and cell types during zebrafish organogenesis.

Cell-type specific expression of connexins in the integument in vivo

To validate that the connexin expression identified in the updated atlas related to in vivo tissues and cell types, we examined the integument, or the embryonic skin, as it represented 


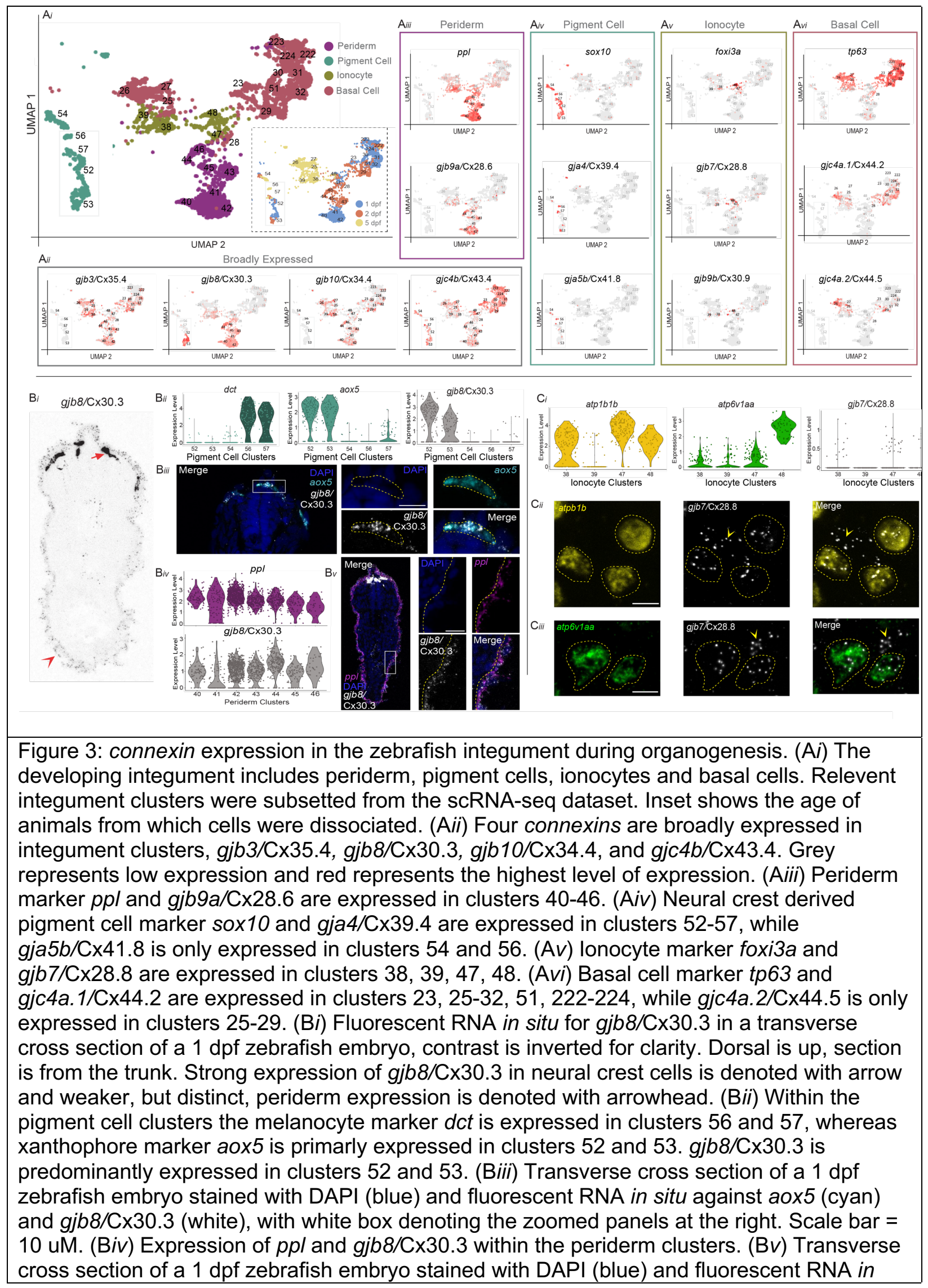


situ against $\mathrm{ppl}$ (purple) and gjb8/Cx30.3 (white) with white box denoting the zoomed panels at the right. (Ci) Within the ionocyte clusters the $\mathrm{Na}+, \mathrm{K}+-\mathrm{ATP}$ ase-rich cell and H+-ATPaserich cell markers atp $1 \mathrm{~b} 1 \mathrm{~b}$ and atp6v1aa, respectively, are expressed in conjunction with low expression of gjb7/Cx28.8. (Cii) Fluorescent RNA in situ in a 1dpf zebrafish embryo against atp $1 b 1 b$ (yellow), gjb7/Cx28.8 (white), with merged signal (right). atp1b1b expressing cells are outlined with a dashed yellow line, and gjb7/Cx28.8 signal outside of those cells are marked with yellow arowhead. Scale bar $=10 \mathrm{uM}$. (Ciii) Fluorescent RNA in situ in a 1dpf zebrafish embryo against atp6v1aa (green), gjb7/Cx28.8 (white), with merged signal (right). atp6v1aa expressing cells are outlined with a dashed yellow line, and gjb7/Cx28.8 signal outside of those cells are marked with yellow arowhead. Scale bar $=10 \mathrm{uM}$.

one of the most striking trends of combinatorial expression (Fig. 2). Throughout zebrafish organogenesis, the integument is composed of distinct cellular populations including the periderm (the outermost epidermal layer), the basal cells (a keratinocyte stem cell population), the ionocytes (epithelial cells that maintain osmotic homeostasis), and the pigment cells (neural crest derived cells that provide pigmentation) ${ }^{116,117}$. These individual cell populations are molecularly identifiable using distinct markers including ppl (periderm) ${ }^{104,109}$, tp63 (basal cells) ${ }^{118}$, foxi3a (ionocytes) ${ }^{119}$, and sox10 (pigment cells) ${ }^{116,120}$ (Fig. 3; Supp. Fig. 8). We used these canonical markers in conjunction with our annotations (Supp. Fig. 8; Supp. Table 2) to identify clusters that represent all four cell types of the integument (Fig. 3Ai). We identified all connexins that are significantly expressed within these presumptive integument clusters (Fig. 3; Supp. Fig. 8). We found that gjb3/Cx35.4, gjb8/Cx30.3, gjb10/Cx34.4, and gjc4b/Cx43.4 are expressed broadly across these clusters (Fig. 3Aii). We then looked for connexins enriched in subsets of clusters and found unique and specific patterns of expression. Within periderm clusters, we discovered gjb9a/Cx28.6, which has not previously been documented in the skin (Fig. 3Aiii). Within the presumptive neural crest derived pigment clusters, we found gja4/Cx39.4 and gja5b/Cx41.8, which are both known to contribute to adult zebrafish skin patterns ${ }^{49,71}$ (Fig. 3Aiv). Within ionocyte clusters, we identified novel expression for two connexins, gjb7/Cx28.8 and gjb9b/Cx30.9 (Fig. 3Av). Finally, within presumptive basal cell clusters, we found novel expression for two connexins, gjc4a.1/Cx44.2 and gjc4a.2/Cx44.5 (Fig. 3Avi). These results suggest the integument uses a complex set of connexins throughout organogenesis.

We next examined a subset of the identified integument connexins in vivo. We first tested a broadly expressed connexin, gjb8/Cx30.3, to see if it was expressed in the pigment cells and periderm using fluorescent RNA in situ on $1 \mathrm{dpf}$ embryos. Transverse cross sections through the trunk revealed prominent gjb8/Cx30.3 staining in dorsally located cells near the 
neural tube and additional dim staining was observed in a single layer of cells surrounding the entire embryo (Fig. 3Bi). We first confirmed gjb8/Cx30.3's expression in pigment cells by subsetting the five clusters that appear to represent pigment cells, including melanophores ${ }^{121,122}$ (dct+, clusters 56, 57, Fig. 3 Bii; Supp. Table 2) and xanthophores ${ }^{123}$ (aox5+, clusters 52, 53, Fig. 3 Bii; Supp. Table 2). We find that $g j b 8 / C \times 30.3$ is highly expressed in only the presumptive xanthophore clusters (Fig. 3 Bii). We then performed fluorescent RNA in situ for aox 5 and gjb8/Cx30.3 in a $1 \mathrm{dpf}$ embryo and found robust co-localization of these transcripts, confirming that $g j b 8 / C \times 30.3$ is expressed in xanthophore cells (Fig. 3Biii). We then examined gjb8/Cx30.3's expression in the periderm through sub-setting the seven presumptive periderm clusters ( $p p /+$, clusters 40-46, Supp. Table 2) and find expression of gjb8/Cx30.3 in all clusters (Fig. 3 Biv). Indeed, fluorescent RNA in situ for $\mathrm{ppl}$ and gjb8/Cx30.3 reveal robust co-localization of these transcripts in the outermost epithelial layer (Fig. 3Bv), confirming that gjb8/Cx30.3 is expressed in the developing periderm.

We next tested a connexin with more specific expression within the integument clusters, gjb7/Cx28.8, which has expression specific to the presumptive ionocytes (Fig. 3Av). Developing foxi3a+ ionocytes form $\mathrm{Na}+, \mathrm{K}+-$ ATPase-rich ( $\mathrm{NaR}$ ) cells or $\mathrm{H+-ATPase-rich} \mathrm{(HR)} \mathrm{cells,} \mathrm{which}$ are characterized by the expression of the specific ATPase genes atp $1 \mathrm{~b} 1 \mathrm{~b}$ and atp $6 \mathrm{v} 1 \mathrm{aa}$, respectively ${ }^{119}$. First, we sub-setted all ionocyte clusters ${ }^{119}$ (foxi3a+, 38, 39, 47, 48) and found unique expression combinations of atp $1 \mathrm{~b} 1 \mathrm{~b}$ and atp $6 \mathrm{v} 1 \mathrm{aa}$ across clusters and low expression of gjb7/Cx28.8 in 3 of 4 clusters (Fig. 3Ci). Fluorescent RNA in situ revealed co-localization of gjb7/Cx28.8 with both atp1b1b (Fig. 3Cii) and atp6v1aa (Fig. 3Ciii), confirming that gjb7/Cx28.8 is expressed in ionocytes. Together, these data confirm the predictive power of the scRNA-seq dataset for connexin expression in the integument and support the utility of the dataset as a novel tool for discovery of investigating connexin complexity in vertebrate development.

\section{Discussion}

Here we reveal the details of connexin gene-family expression during zebrafish organogenesis showing that connexin usage is widespread yet displays gene-specific variations across tissue, cell type, and developmental time. The large gene family of connexins in zebrafish (41 genes) is expressed in complex patterns ranging from nearly ubiquitous to celltype specific, with unique combinatorial and nested expression sets restricted to individual tissues. Temporally, connexins display sustained, increasing, and diminishing expression profiles across development, dependent upon gene and tissue. Together, these data reveal the 
complexity of expression of this critical gene family in a model vertebrate and demonstrate that this critical form of communication is likely to be used by all tissues during organogenesis. These data provide a critical framework facilitating analysis of how these genes contribute to cellular communication in tissues developing from all germ layers, providing a basis to understand connexins in development and in modeling human disease.

We find that all cells express connexins, but each tissue expresses a unique combinations of the gene family with the composition of the expressed set evolves over developmental time. This spatiotemporal complexity of connexin family usage likely contributes to both functional redundancy within tissues as well as functional diversity. The many connexins expressed might allow for a myriad of combinatorial interactions amongst Connexin proteins, which could contribute to heteromeric hemichannels and heterotypic GJs. Importantly, Connexins can only interact with potential partners if they are expressed in the same cell or between interacting cells, thus the work here constrains the combinatorial problem of complex usage by revealing the details of the expression patterns through organogenesis. For example, gjd2a/Cx35.5 and gjd1a/Cx34.1 have been shown to form heterotypic GJs (unique Connexins on each side of the GJ) at electrical synapses of the Mauthner cell neural circuit ${ }^{45}$. The data here shows extensive overlapping expression of these two connexins throughout the central nervous system, suggesting complex hemi-channels and GJs could be common throughout the brain. Given that each Connexin-mediated hemichannel has its own unique set of compatibilities and permeability properties, this dataset provides a platform for future research to explore whether connexins expressed within the same tissue or cell type form functional channels, and how the molecular identity of these channels influences function.

This dataset presents as a powerful resource for zebrafish and connexin biology. We establish connexin expression in cells previously unknown to express connexins, such as the ionocytes of the skin. Within our dataset there are numerous other cell types with striking connexin expression patterns that have under-appreciated connexin usage inviting exploration, including macrophages (gja13.2/Cx32.2) and primordial germ cells (gja9a/Cx55.5, gjb8/Cx30.3, gjc4b/Cx43.4 and gjd1b/Cx34.7). Another strength of this dataset is the exploration of expression across multiple cell types, tissues, and timepoints simultaneously. For example, gja3/Cx46 has only been examined in the heart ${ }^{65,66}$, yet, in our dataset we find robust gja3/Cx46 expression in both heart and lens clusters, which suggests an enticing link to human GJA3/CX46, in which mutations are associated with cataracts ${ }^{67-69}$. Finally, this dataset provides putative expression to many connexin genes that had no previous expression information (22/41 genes). For example, gjb1a/Cx27.5 and gjc2/Cx47.1 are both highly expressed in the Schwann 
cell cluster. While neither of these genes had previously known expression information, mutations of their human orthologs GJB1/CX32 and GJC2/CX47 contribute to neuropathy and myelin disorders ${ }^{86,93,94}$. The identification of tissues and cell type expression patterns for the entire gene family creates a basis to explore connexin related diseases in zebrafish and provide comparisons to human biology. Through exploring the connexin family expression across diverse cell types and tissues, we can begin to envision a holistic view of Connexins utilization and usage in cellular communication throughout organogenesis.

\section{Methods}

scRNA-seq

\section{Embryo dissociation and cDNA library prep}

As described by Farnsworth et al., 202048, larvae from the Tg(olig2:GFP)vu12 and Tg(elav/3:GCaMP6s) backgrounds were pooled ( $\mathrm{n}=15$ per replicate), with 2 replicates at each sampled timepoint (1, 2, 5dpf). Cells from entire larvae were dissociated using standard protocols. Dissociated cells were then run on a 10X Chromium platform using 10x v.2 chemistry aiming for 10,000 cells per run.

\section{Alignment}

To ensure that the full transcripts of the Connexin-encoding genes were represented in the dataset, we used gene models with lengthened 3' UTRs across the zebrafish genome generated and validated by the Lawson $\operatorname{Lab}^{100}$. We ensured that the connexin genes were annotated properly by comparing pooled deep-sequencing information and extended the 3' UTR regions as needed. Using this updated GTF file, we aligned reads to the zebrafish genome, GRCz11_93, using the 10X Cellranger pipeline (version 3.1).

\section{Computational Analysis}

Cells were analyzed using the Seurat (V3.1.5) software package for R (V4.1.0) using standard quality control, normalization, and analysis steps. We performed PCA using 115 PCs based on a Jack Straw-determined significance of $P<0.01$. UMAP analysis was performed on the resulting 49,367 cells with 115 PC dimensions and a resolution of 15.0, which produced 238 clusters. 


\section{Cluster annotation}

The unique barcode assigned to each cell was extracted from the original Farnsworth dataset ${ }^{48}$ and identified in our updated dataset. For each updated cluster, we analyzed the percentage of cells contributing which were associated with the original Farnsworth's clusters. Frequently, we found the updated dataset contained clusters with a significant proportion of cells (>80\%) from a single Farnsworth cluster, and in such we transferred the annotation from the original cluster to the updated cluster. We also found instances of a single Farnsworth cluster breaking nearly evenly across two of the updated clusters - for example, the original dataset had a single 'photoreceptor' cluster (cluster 115), whereas the updated data had two clusters (clusters 13, 14) with cells from original photoreceptor cluster. Further analysis revealed that these two new clusters represented likely rods and cones. Finally, we also found updated clusters that did not have a clear previous annotation. In these instances, we analyzed the most differentially expressed genes from that cluster and compared them with canonical markers.

\section{Fluorescent RNA in-situ}

Custom RNAscope probes to target connexin genes were designed and ordered through ACD (https://acdbio.com/). For the fluorescent in situs, we used a modified RNAscope protocol ${ }^{124}$. Briefly, $1 \mathrm{dpf}$ embryos were fixed for 2 hours at room temp in 4\% PFA and then stored in 100\% methanol at $-20 \mathrm{C}$. The tissue was then exposed to protease plus for $30 \mathrm{~min}$, washed with PBS with $1 \%$ Triton X (PBSTx), and then hybridized with the 1x probe overnight at 40C. Standard RNAscope V2 multiplex reagents and Opal fluorophores were used, with the modification that PBSTx which was used for all wash steps. Stained tissue was either mounted (whole mount) or immediately cryo-sectioned and mounted with ProLong Gold Antifade (ThermoFisher).

\section{Zebrafish Husbandry}

Fish were maintained by the University of Oregon Zebrafish Facility using standard husbandry techniques ${ }^{125}$. Embryos were collected from natural matings, staged, and pooled. Animals used in the original Farnsworth data were: $\operatorname{Tg}(o l i g 2: G F P) v u 12$ and $T g(e l a v / 3: G C a M P 6 s)^{48}$, and animals used for RNAscope in situs were ABC-WT. Animal use protocol AUP-18-35 was approved by the University of Oregon IACUC committee and animal work was overseen by Dr. Kathy Snell. 


\section{Acknowledgments}

We thank the entire Miller Lab ongoing support, comments, and discussions on this manuscript. We thank Clay Small for discussions and expertise in regards to data handling, statistics, and annotation transfer from the original to updated atlas. We thank the University of Oregon AqACS facility for superb animal care. We thank the ZFIN team, and Svein-Ole Mikalsen, for communication regarding the connexin gene names. This work was supported by the $\mathrm{NIH}$ National Institute of General Medical Sciences, Genetics Training Grant T32GM007413 to R.M.L., and the NIH Office of the Director R24OD026591 and the NIH National Institute of Neurological Disorders and Stroke R01NS105758 to A.C.M.

\section{Data availability}

All data generated or analyzed during this study are included in the published article and its supplementary information files. Sequences used in this study were deposited to the NCBI SRA and can be found using the identifier PRJNA564810. Additional files, including the updated GTF and analysis, can be found at https://www.adammillerlab.com/. 
Supplemental Figure Legends:

Supplemental Figure 1: Phylogeny of human $(h s)$ and zebrafish $(d r)$ Connexin proteins.

Supplemental Figure 2: Protein similarities and phylogeny of the novel gjz1/Cx26.3. (A) Zebrafish (dr.) Gjz1/Cx26.3 aligned with the most similar human (hs.) Connexin protein, GJB3. The predicted intercellular portions (coral), transmembrane domains (green) and extracellular loops (blue) for GJB3 are denoted above the sequence. (B) Ensembl-generated phylogenetic tree of gjz1/Cx26.3 (si:rp71-1c10.10 in red). Bony fishes are highlighted in pink, while lobed-fin lineages from coelacanth to mammals are in other colors. Protacanthopterygii and Euacanthomorphacea sub-trees are collapsed for visual purposes (grey triangle). Each related gene is represented on a node and colored based on Ensembl predications, including a gene node (white box), speciation nodes (dark blue box), duplication nodes (red box), and ambiguous nodes (teal box). Genomic sequence alignment similarity is denoted on the right with black boxes (representing 66-100\% alignment), moderate sequence alignment is denoted on the right with green boxes (representing 33-66\% sequence alignment) and gaps in alignments are denoted in white.

Supplemental Figure 3: Gene model updates to capture connexin expression. (A) Aligned sequencing view showing coverage pileups for scRNA-seq (1, 2, $5 \mathrm{dpf}$ ) and bulk RNA-seq, as well as bulk RNA-seq reads (grey boxes). The Ensembl GTF (light green) captures few reads associated with gjd4/Cx46.8. Extending the gene model (dark green) in the updated GTF captures these missed transcripts. (B) Comparisons between the Farnsworth et al., 2020 dataset and the updated dataset. $(\mathrm{Bi})$ Farnsworth cluster 57 has robust expression of slow muscle marker smyhc2, but poor expression of gjd4/Cx46.8. In the updated dataset, the related cluster 4 has similar expression of slow muscle marker smyhc2 but a significant increase of gjd4/Cx46.8 representation (right). (Bii) Farnsworth cluster 205 has robust expression of cardiac muscle marker myl17 and gjd6/Cx36.7. The corresponding cluster in the updated dataset did not significantly alter either of these expression patterns (right). (Biii) Farnsworth cluster 173 has low expression of Schwann Cell marker, mbpa, as well as gjb1a/Cx27.5. The corresponding cluster in the updated dataset captures robust expression for both $\mathrm{mbpa}$ and gjb1a/Cx27.5.

Supplemental Figure 4: connexin expression throughout the atlas. Note that this figure extends across 41 pages, one for each connexin gene, labeled A-OO. Expression of each connexin is plotted on the scRNAseq atlas and visualized through color intensity on UMAP plots and by violin plots for each gene and cluster.

Supplemental Figure 5: Tissue and cell type markers with corresponding connexin expression. (Ai) Central nervous system clusters express snap25a and pcna, and gjc4b/Cx43.4. (Aii) Lens clusters (193, 112 and 237) express lens markers crybb1 and crybab2, and gja8b/Cx44.1. (Aiii) Skeletal muscle clusters express slow muscle marker smyhc1 $(4,5,234)$, fast muscle marker myhz2 (7, 8, 9, 10, 11, 233), and gja2/Cx39.9. (Aiv) Cardiac muscle cluster 233 expresses markers nppa and myl17, and gjd6/Cx36.7. (Av) Retinal horizonal neurons, cluster 203, express marker $m d k a$ and gja9b/Cx52.9 and gja10b/Cx52.6.

Supplemental Figure 6: Temporal expression patterns of connexins within the intestine. (Ai) Intestinal clusters $(3,60,67,140)$ selected for expression of canonical markers cldnc, fabp2, and foxa3. (Aii) These clusters display an evolution of connexin expression at different 
developmental time points. gjc4b/Cx43.4 (left) is expressed at 1 and $2 \mathrm{dpf}$, gja13.1/Cx23.3 is expressed at 2 and $5 \mathrm{dpf}$, and gja12.1/Cx28.9 is expressed at $5 \mathrm{dpf}$.

Supplemental Figure 7: Primordial germ cells express several connexins. Putative primordial germ cell (PGC) cluster (128) expressing PGC markers like $d d x 4$ and nanos3, in addition to connexins including gja9a/Cx55.5, gjb8/Cx30.3, gjc4b/Cx43.4, and gjd1b/Cx34.7.

Supplemental Figure 8: connexin expression in the integument. Clusters classified into cell types are grouped and labelled accordingly. (Ai) gjb3/Cx35.4, gjb8/Cx30.3, gjb10/Cx34.4, and gjc4b/Cx43.4 are all expressed broadly through the integument clusters. (Aii) ppl, krt4, and evpla are expressed highly in periderm clusters, with gjb9a/Cx28.6 being primarily expressed in periderm clusters. (Aiii) sox 10 and aox 5 expression identifying pigment cell clusters with gja4/Cx39.4 and gja5b/Cx41.8. (Aiv) foxi3a expression identifying ionocyte clusters with gjb7/Cx28.8 and gjb9b/Cx30.9. (Av) tp63 expression identifying basal cell clusters with gjc4a.1/Cx44.2 and gjc4a.2/Cx44.5.

Supplemental Table 1: The zebrafish connexin family.

Supplemental Table 2: Transferring Farnsworth et. al, 2020 cluster annotations to the updated dataset. Updated cluster number (Column A) and the corresponding Farnsworth cluster (Column B). The count of cells from the Farnsworth cluster that ended in the corresponding updated cluster (Column $\mathrm{C}$ ), and the proportion of cells from a given Farnsworth cluster that contribute to the updated cluster (Column D, E). Total cell counts are colored in blue and bolded. All previous Farnsworth annotations were transferred over (columns H-AE), and update cluster markers are included in orange. The most significant Farnsworth cluster contributor is denoted in black font.

Supplemental Table 3: List of differentially expressed genes for each cluster. (Sheet1) For each cluster (Column A), annotations at germ layer, tissue, cell type, and subtype (Columns B - E) level are listed. For each cluster, the top 16 most differentially expressed genes are listed (Column F - U). (Sheet 2) All differentially expressed genes for each updated cluster, generated using the FindAllMarkers command of Seurat, using the Wilcoxon rank sum test. Pct.1 (Column D) and Pct.2 (Column E) reflect the fraction of cells expressing each marker gene (Boolean) within each cluster and for all other cells, respectively.

Supplemental Table 4: The proportion of cells within each cluster that express each connexin.

Supplemental Table 5: All reagents used for fluorescent RNA in-situ and other immunohistochemistry in this study. 


\section{References}

1. Evans, W. H. et al. Gap junctions : structure and function (Review ) Gap junctions : structure and function ( Review ). 7688, (2009).

2. Xing, L., Yang, T., Cui, S. \& Chen, G. Connexin Hemichannels in Astrocytes : Role in CNS Disorders. 12, 1-10 (2019).

3. Orellana, J. A., Martinez, A. D. \& Retamal, M. A. Gap junction channels and hemichannels in the CNS: regulation by signaling molecules. Neuropharmacology 75 , 567-582 (2013).

4. Beyer, E. C. \& Berthoud, V. M. Gap junction gene and protein families: Connexins, innexins, and pannexins. Biochimica et Biophysica Acta (BBA) - Biomembranes 1860, 58 (2018).

5. Alexopoulos, H. et al. Evolution of gap junctions : the missing link? Current Biology 14, 879-880 (2004).

6. Tishchenko, A., Azor, D. D. \& Vidal-brime, L. Cx43 and Associated Cell Signaling Pathways. Cancers 1-25 (2020).

7. Okafo, G., Prevedel, L. \& Eugenin, E. Tunneling nanotubes ( TNT ) mediate long-range gap junctional communication : Implications for HIV cell to cell spread. Scientific Reports 1-9 (2017) doi:10.1038/s41598-017-16600-1.

8. Soares, A. R. et al. Gap junctional protein Cx43 is involved in the communication between extracellular vesicles and mammalian cells. Nature Publishing Group 1-14 (2015) doi:10.1038/srep13243.

9. Oyamada, M., Oyamada, Y. \& Takamatsu, T. Regulation of connexin expression. Biochimica et Biophysica Acta 1719, 6-23 (2005).

10. Chanson, M., Watanabe, M. \& Martin, P. E. Connexin Communication Compartments and Wound Repair in Epithelial Tissue. International Journal of Molecular Sciences 19, 1-19 (2018).

11. Rozental, R. Gap junctions in the nervous system. Brain Researach Reviews 32, 11-15 (2000).

12. Figueroa, X. F. \& Duling, B. R. Gap Junctions in the Control of Vascular Function. ANTIOXIDANTS \& REDOX SIGNALING 11, (2009).

13. Richard, G. Connexin disorders of the skin. Clinics in Dermatology 23, 23-32 (2005).

14. Richard, G. et al. Missense Mutations in GJB2 Encoding Connexin-26 Cause the Ectodermal Dysplasia Keratitis-Ichthyosis-Deafness Syndrome. The American Journal of Human Genetics 70, 1341-1348 (2002).

15. Richard, G. et al. Mutations in the human connexin gene GJB3 cause erythrokeratodermia variabilis. Nature Genetics 20, 366-369 (1998).

16. Richard, G. et al. The spectrum of mutations in erythrokeratodermias--novel and de novo mutations in GJB3. Human genetics 106, 321-329 (2000).

17. Willoughby, C. E. et al. A novel \&lt;em\&gt;GJA8\&lt;/em\&gt; mutation in an Iranian family with progressive autosomal dominant congenital nuclear cataract. Journal of Medical Genetics 40, e124 LP-e124 (2003).

18. Wei, C., Xu, X. \& Lo, C. W. Connexins and Cell Signaling in Development and Disease. Annu. Rev. Cell Dev. Biol 20, 811-38 (2004).

19. Kelsell, D. P. et al. Connexin 26 mutations in hereditary non-syndromic sensorineural deafness. Nature 387, 80-83 (1997).

20. Grifa, A. et al. Mutations in GJB6 cause nonsyndromic autosomal dominant deafness at DFNA3 locus. Nature Genetics 23, 16-18 (1999).

21. Xia., J. et al. Mutations in the gene encoding gap junction protein $\beta-3$ associated with autosomal dominant hearing impairment. Nature Genetics 20, 370-373 (1998). 
22. Jongsma, H. J. \& Wilders, R. Gap Junctions in Cardiovascular Disease. 1193-1197 (2000).

23. Yeh, H.-I., Chou, Y., Liu, H.-F., Chang, S.-C. \& Tsai, C.-H. Connexin37 gene polymorphism and coronary artery disease in Taiwan. International Journal of Cardiology 81, 251-255 (2001).

24. Li, W. E. I. et al. An essential role for connexin43 gap junctions in mouse coronary artery development. Development (Cambridge, England) 129, 2031-2042 (2002).

25. Maes, M., Cogliati, B., Crespo Yanguas, S., Willebrords, J. \& Vinken, M. Roles of connexins and pannexins in digestive homeostasis. Cellular and molecular life sciences: CMLS 72, 2809-2821 (2015).

26. Maes, M., Crespo Yanguas, S., Willebrords, J., Cogliati, B. \& Vinken, M. Connexin and pannexin signaling in gastrointestinal and liver disease. Translational research : the journal of laboratory and clinical medicine 166, 332-343 (2015).

27. Temme, A. et al. High incidence of spontaneous and chemically induced liver tumors in mice deficient for connexin32. Current Biology 7, 713-716 (1997).

28. Eastman, S. D., Chen, T. H. P., Falk, M. M., Mendelson, T. C. \& lovine, M. K. Phylogenetic analysis of three complete gap junction gene families reveals lineagespecific duplications and highly supported gene classes. Genomics 87, 265-274 (2006).

29. Mikalsen, S. Evolutionary selection pressure and family relationships among connexin genes a. 388, 253-264 (2007).

30. Mikalsen, S. \& Tausen, M. Phylogeny of teleost connexins reveals highly inconsistent intra- and interspecies use of nomenclature and misassemblies in recent teleost chromosome assemblies. BMC Genomics 1-19 (2020).

31. Tarzemany, R., Jiang, G., Jiang, J. X., Larjava, H. \& Häkkinen, L. Connexin 43 Hemichannels Regulate the Expression of Wound Healing-Associated Genes in Human Gingival Fibroblasts. Scientific Reports 7, 1-15 (2017).

32. He, D. S., Jiang, J. X., Taffet, S. M. \& Burt, J. M. Formation of heteromeric gap junction channels by connexins 40 and 43 in vascular smooth muscle cells. Proceedings of the National Academy of Sciences 96, 6495 LP - 6500 (1999).

33. Brink, P. R. et al. Evidence for heteromeric gap junction channels formed from rat connexin43 and human connexin37. The American journal of physiology 273, C1386-96 (1997).

34. Koval, M., Molina, S. A. \& Burt, J. M. Mix and match: Investigating heteromeric and heterotypic gap junction channels in model systems and native tissues. FEBS Lett $\mathbf{5 8 8}$, 1193-1204 (2015).

35. Koval, M. Pathways and control of connexin oligomerization. Trends in cell biology 16, 159-166 (2006).

36. Bruzzone, R., Haefliger, J. A., Gimlich, R. L. \& Paul, D. L. Connexin40, a component of gap junctions in vascular endothelium, is restricted in its ability to interact with other connexins. Molecular biology of the cell 4, 7-20 (1993).

37. C. Elfgang H. Lichtenberg-Frate, A. Butterweck, O. Traub, R. A. Klein, D. F. Hulser, and K. Willeck, R. E. et al. Specific permeability and selective formation of gap junction channels in connexin-transfected HeLa cells. Journal of Cell Biology 129, 805-817 (1995).

38. Weber, P. A., Chang, H. C., Spaeth, K. E., Nitsche, J. M. \& Nicholson, B. J. The permeability of gap junction channels to probes of different size is dependent on connexin composition and permeant-pore affinities. Biophysical Journal 87, 958-973 (2004).

39. Grueterich, M., Espana, E. \& Tseng, S. C. G. Connexin 43 expression and proliferation of human limbal epithelium on intact and denuded amniotic membrane. Investigative ophthalmology \& visual science 43, 63-71 (2002). 
40. Beardslee, M. A., Laing, J. G., Beyer, E. C. \& Saffitz, J. E. Rapid turnover of connexin43 in the adult rat heart. Circulation research 83, 629-635 (1998).

41. Contreras, J. E. et al. Metabolic inhibition induces opening of unapposed connexin 43 gap junction hemichannels and reduces gap junctional communication in cortical astrocytes in culture. Proceedings of the National Academy of Sciences of the United States of America 99, 495-500 (2002).

42. Srinivas, M. et al. Functional properties of channels formed by the neuronal gap junction protein connexin36. Journal of Neuroscience 19, 9848-55 (1999).

43. Nadarajah, B., Jones, A. M., Evans, W. H. \& Parnavelas, J. G. Differential Expression of Connexins during Neocortical Development and Neuronal Circuit Formation. J. Neuroscience 17, 3096-3111 (1997).

44. Locke, D. et al. Developmental Expression and Assembly of Connexins Into Homomeric and Heteromeric Gap Junction Hemichannels in the Mouse Mammary Gland. 237, 228237 (2000).

45. Miller, A. C. et al. A genetic basis for molecular asymmetry at vertebrate electrical synapses. eLife 6, (2017).

46. Lasseigne, A. M. et al. Electrical synaptic transmission requires a postsynaptic scaffolding protein. eLife 10, e66898 (2021).

47. Plum, A. et al. Unique and shared functions of different connexins in mice. Current Biology 10, 1083-1091 (2000).

48. Farnsworth, D. R., Saunders, L. M. \& Miller, A. C. A single-cell transcriptome atlas for zebra fi sh development. Developmental Biology (2019) doi:10.1016/j.ydbio.2019.11.008.

49. Watanabe, M. Gap Junction in the Teleost Fish Lineage : Duplicated Connexins May Contribute to Skin Pattern Formation and Body Shape Determination. Frontiers in Cell and Developmental Biology 5, 1-8 (2017).

50. Bruford, E. A. et al. Guidelines for human gene nomenclature. Nature genetics 52, 754 758 (2020).

51. Sprague, J., Doerry, E., Douglas, S. \& Westerfield, M. The Zebrafish Information Network (ZFIN): a resource for genetic, genomic and developmental research. Nucleic acids research 29, 87-90 (2001).

52. Snoeckx, R. L. et al. GJB2 mutations and degree of hearing loss: a multicenter study. American journal of human genetics 77, 945-957 (2005).

53. Chang-Chien, J. et al. The connexin 30.3 of zebrafish homologue of human connexin 26 may play similar role in the inner ear. Hearing Research 313, 55-66 (2014).

54. Dasgupta, C. et al. Identification of connexin43 ( $\alpha 1$ ) gap junction gene mutations in patients with hypoplastic left heart syndrome by denaturing gradient gel electrophoresis (DGGE). Mutation Research/Fundamental and Molecular Mechanisms of Mutagenesis 479, 173-186 (2001).

55. Paznekas, W. A. et al. Connexin 43 (GJA1) Mutations Cause the Pleiotropic Phenotype of Oculodentodigital Dysplasia. The American Journal of Human Genetics 72, 408-418 (2003).

56. Paznekas, W. A. et al. GJA1 mutations, variants, and connexin 43 dysfunction as it relates to the oculodentodigital dysplasia phenotype. Human Mutation 30, 724-733 (2009).

57. Brice, G. et al. A novel mutation in GJA1 causing oculodentodigital syndrome and primary lymphoedema in a three generation family. Clinical Genetics 84, 378-381 (2013).

58. Hu, Y. et al. A Novel Autosomal Recessive GJA1 Missense Mutation Linked to Craniometaphyseal Dysplasia. PLOS ONE 8, e73576 (2013).

59. Haffter, P. et al. Mutations affecting pigmentation and shape of the adult zebrafish. Development Genes and Evolution 206, 260-276 (1996). 
60. Henke, K. et al. Genetic Screen for Postembryonic Development in the Zebrafish (Danio rerio): Dominant Mutations Affecting Adult Form. Genetics 207, 609-623 (2017).

61. Misu, A. et al. Two Different Functions of Connexin43 Confer Two Different Bone Phenotypes in Zebrafish *. Journal of Biological Chemistry 291, 12601-12611 (2016).

62. Hoptak-solga, A. D. et al. Connexin43 ( GJA1) is required in the population of dividing cells during fi $n$ regeneration. Developmental Biology 317, 541-548 (2008).

63. Zhang, J. et al. Wnt-PLC-IP3-Connexin-Ca2+ axis maintains ependymal motile cilia in zebrafish spinal cord. Nature Communications (2020) doi:10.1038/s41467-020-15248-2.

64. Hirata, H. et al. Connexin 39.9 protein is necessary for coordinated activation of slowtwitch muscle and normal behavior in zebrafish. Journal of Biological Chemistry 287, 1080-1089 (2012).

65. Chi, N. C. et al. Cardiac conduction is required to preserve cardiac chamber morphology. Proceedings of the National Academy of Sciences 107, 14662 LP - 14667 (2010).

66. Chi, N. C. et al. Genetic and Physiologic Dissection of the Vertebrate Cardiac Conduction System. PLOS Biology 6, e109 (2008).

67. Mackay, D. et al. Connexin46 Mutations in Autosomal Dominant Congenital Cataract. The American Journal of Human Genetics 64, 1357-1364 (1999).

68. Burdon, K. P. et al. A novel mutation in the Connexin 46 gene causes autosomal dominant congenital cataract with incomplete penetrance. Journal of Medical Genetics 41, e106 LP-e106 (2004).

69. Yao, K. et al. A novel GJA3 mutation associated with congenital nuclear pulverulent and posterior polar cataract in a chinese family. Human Mutation 32, 1367-1370 (2011).

70. Yang, Y.-Q. et al. Connexin40 nonsense mutation in familial atrial fibrillation . Int J Mol Med 26, 605-610 (2010).

71. Watanabe, M., Sawada, R., Aramaki, T., Skerrett, I. M. \& Kondo, S. The Physiological Characterization of Connexin41.8 and Connexin39 . 4, Which Are Involved in the Striped Pattern Formation of Zebrafish *. The Journal of Biological Chemistry 291, 10531063 (2016).

72. Denis, J.-F. et al. KLF4-Induced Connexin40 Expression Contributes to Arterial Endothelial Quiescence . Frontiers in Physiology vol. 1080 (2019).

73. Groenewegen, W. A. et al. A Cardiac Sodium Channel Mutation Cosegregates With a Rare Connexin40 Genotype in Familial Atrial Standstill. Circulation Research 92, 14-22 (2003).

74. Makita, N. et al. Congenital atrial standstill associated with coinheritance of a novel SCN5A mutation and connexin 40 polymorphisms. Heart Rhythm 2, 1128-1134 (2005).

75. Gollob, M. H. et al. Somatic Mutations in the Connexin 40 Gene (GJA5) in Atrial Fibrillation. New England Journal of Medicine 354, 2677-2688 (2006).

76. Wirka, R. C. et al. A Common Connexin-40 Gene Promoter Variant Affects Connexin-40 Expression in Human Atria and Is Associated With Atrial Fibrillation. Circulation: Arrhythmia and Electrophysiology 4, 87-93 (2011).

77. Frohnhöfer, H. G. et al. Spermidine, but not spermine, is essential for pigment pattern formation in zebrafish. Biology Open 5, 736-744 (2016).

78. Berry, V. et al. Connexin 50 mutation in a family with congenital "zonular nuclear" pulverulent cataract of Pakistani origin. Human Genetics 105, 168-170 (1999).

79. Polyakov, A. V, Shagina, I. A., Khlebnikova, O. V \& Evgrafov, O. V. Mutation in the connexin 50 gene (GJA8) in a Russian family with zonular pulverulent cataract. Clinical Genetics 60, 476-478 (2001).

80. Hansen, L. et al. Genetic Heterogeneity in Microcornea-Cataract: Five Novel Mutations in CRYAA, CRYGD, and GJA8 . Investigative Ophthalmology \& Visual Science 48, 39373944 (2007). 
81. Ping, X. et al. Rapamycin relieves the cataract caused by ablation of Gja8b through stimulating autophagy in zebrafish. Autophagy 1-15 (2021)

doi:10.1080/15548627.2021.1872188.

82. Klaassen, L. J. et al. Synaptic Transmission from Horizontal Cells to Cones Is Impaired by Loss of Connexin Hemichannels. PLOS Biology 9, e1001107 (2011).

83. Ionasescu, V., Ionasescu, R. \& Searby, C. Correlation between connexin 32 gene mutations and clinical phenotype in X-linked dominant Charcot-Marie-tooth neuropathy. American Journal of Medical Genetics 63, 486-491 (1996).

84. Bergoffen, J. et al. Connexin mutations in X-linked Charcot-Marie-Tooth disease. Science (New York, N.Y.) 262, 2039-2042 (1993).

85. Charlton-Perkins, M., Almeida, A. D., MacDonald, R. B. \& Harris, W. A. Genetic control of cellular morphogenesis in Müller glia. Glia 67, 1401-1411 (2019).

86. López-Bigas, N. et al. Connexin 31 (GJB3) is expressed in the peripheral and auditory nerves and causes neuropathy and hearing impairment. Human Molecular Genetics 10, 947-952 (2001).

87. Willems, P. J. Genetic Causes of Hearing Loss. New England Journal of Medicine 342, 1101-1109 (2000).

88. Iossa, S., Marciano, E. \& Franzé, A. GJB2 Gene Mutations in Syndromic Skin Diseases with Sensorineural Hearing Loss. Current genomics 12, 475-785 (2011).

89. del Castillo, I. et al. A Deletion Involving the Connexin 30 Gene in Nonsyndromic Hearing Impairment. New England Journal of Medicine 346, 243-249 (2002).

90. Lamartine, J. et al. Mutations in GJB6 cause hidrotic ectodermal dysplasia. Nature Genetics 26, 142-144 (2000).

91. Okamoto, R. et al. Gap junction protein beta 4 plays an important role in cardiac function in humans, rodents, and zebrafish. PLOS ONE 15, e0240129 (2020).

92. Macari, F. et al. Mutation in the Gene for Connexin 30.3 in a Family with Erythrokeratodermia Variabilis. The American Journal of Human Genetics 67, 1296-1301 (2000).

93. Uhlenberg, B. et al. Mutations in the Gene Encoding Gap Junction Protein a12 (Connexin 46.6) Cause Pelizaeus-Merzbacher-Like Disease. The American Journal of Human Genetics 75, 251-260 (2004).

94. Orthmann-Murphy, J. L., Enriquez, A. D., Abrams, C. K. \& Scherer, S. S. Loss-of-function GJA12/Connexin47 mutations cause Pelizaeus-Merzbacher-like disease. Molecular and Cellular Neuroscience 34, 629-641 (2007).

95. Ferrell, R. E. et al. GJC2 Missense Mutations Cause Human Lymphedema. The American Journal of Human Genetics 86, 943-948 (2010).

96. Hatler, J. M., Essner, J. J. \& Johnson, R. G. A gap junction connexin is required in the vertebrate left - right organizer. Developmental Biology 336, 183-191 (2009).

97. Wang, J. et al. Epilepsy-associated genes. Seizure 44, 11-20 (2017).

98. Quint, W. H. et al. Loss of Gap Junction Delta-2 (GJD2) gene orthologs leads to refractive error in zebrafish. Communications Biology 2, 1-14.

99. Sultana, N. et al. regulates myofibril orientation and heart morphogenesis by establishing Nkx2 . 5 expression BIOLOGY. 105, (2008).

100. Lawson, N. D. et al. An improved zebrafish transcriptome annotation for sensitive and comprehensive detection of cell type- specific genes. 1-28 (2020).

101. Miller, A. C., Obholzer, N. D., Shah, A. N., Megason, S. G. \& Moens, C. B. RNA-seq based mapping and candidate identification of mutations from forward genetic screens. 679-686 (2013) doi:10.1101/gr.147322.112.23.

102. Zheng, G. X. Y. et al. Massively parallel digital transcriptional profiling of single cells. Nature Communications 8, 14049 (2017). 
103. Satija, R., Farrell, J. A., Gennert, D., Schier, A. F. \& Regev, A. A n a ly s i s Spatial reconstruction of single-cell gene expression data. 33, (2015).

104. Thisse, B., Pflumio, S., Fürthauer, M., Loppin, B., Heyer, V., Degrave, A., Woehl, R., Lux, A., Steffan, T., Charbonnier, X.Q. and Thisse, C. Expression of the zebrafish genome during embryogenesis. ZFIN Direct Data Submission : (Unpublished) (2001).

105. Baxendale, S. et al. Identification of compounds with anti-convulsant properties in a zebrafish model of epileptic seizures. Disease Models \& Mechanisms 5, 773-784 (2012).

106. Wierson, W. A. et al. Efficient targeted integration directed by short homology in zebrafish and mammalian cells. eLife 9, e53968 (2020).

107. lovine, M. K., Higgins, E. P., Hindes, A., Coblitz, B. \& Johnson, S. L. Mutations in connexin43 ( GJA1) perturb bone growth in zebrafish fins. Developmental Biology 278, 208-219 (2005).

108. Chatterjee, B. et al. Developmental Regulation and Expression of the Zebrafish Connexin43 Gene. Developmental Dynamics 233, 890-906 (2005).

109. Thisse, B., Thisse, C. Fast Release Clones: A High Throughput Expression Analysis. ZFIN Direct Data Submission: (Unpublished) (2004).

110. Yang, Y. H. C. et al. Innervation modulates the functional connectivity between pancreatic endocrine cells. bioRxiv 2020.11.04.368084 (2020) doi:10.1101/2020.11.04.368084.

111. Yoshikawa, S. et al. Zebrafish Connexin 79 .8 ( Gja8a ): A Lens Connexin Used as an Electrical Synapse in Some Neurons. 8, 548-561 (2016).

112. Cason, N., White, T. W., Cheng, S. \& Goodenough, D. A. Molecular Cloning, Expression Analysis, and Functional Characterization of Connexin44 . 1: A Zebrafish Lens Gap Junction Protein. Developmental Dynamics 247, 238-247 (2001).

113. Thisse, C., and Thisse, B. High Throughput Expression Analysis of ZF-Models Consortium Clones. ZFIN Direct Data Submission : (Unpublished) (2005).

114. Farnsworth, D. R., Posner, M. \& Miller, A. C. Single cell transcriptomics of the developing zebrafish lens and identification of putative controllers of lens development. Experimental Eye Research 206, 108535 (2021).

115. Greb, H. et al. An Alternative Splice Variant of Zebrafish Cx52.6 is Expressed in Retinal Horizontal Cells. Neuroscience 388, 191-202 (2018).

116. Eisenhoffer, G. T. et al. A toolbox to study epidermal cell types in zebrafish. Journal of cell science 130, 269-277 (2017).

117. Guellec, D. L. E., Morvan-dubois, G. \& Sire, J. Skin development in bony fish with particular emphasis on collagen deposition in the dermis of the zebrafish (Danio rerio ). 231, 217-231 (2004).

118. Lee, H. \& Kimelman, D. A Dominant-Negative Form of p63 Is Required for Epidermal Proliferation in Zebrafish. Developmental Cell 2, 607-616 (2002).

119. Jänicke, M., Carney, T. J. \& Hammerschmidt, M. Foxi3 transcription factors and Notch signaling control the formation of skin ionocytes from epidermal precursors of the zebrafish embryo. Developmental Biology 307, 258-271 (2007).

120. Budi, E. H., Patterson, L. B. \& Parichy, D. M. Embryonic requirements for ErbB signaling in neural crest development and adult pigment pattern formation. Development 135, 2603-2614 (2008).

121. Kelsh, R. N., Schmid, B. \& Eisen, J. S. Genetic Analysis of Melanophore Development in Zebrafish Embryos. Developmental Biology 225, 277-293 (2000).

122. Parichy, D. M., Ransom, D. G., Paw, B., Zon, L. I. \& Johnson, S. L. An orthologue of the kit-related gene fms is required for development of neural crest-derived xanthophores and a subpopulation of adult melanocytes in the zebrafish, Danio rerio. Development (Cambridge, England) 127, 3031-3044 (2000). 
bioRxiv preprint doi: https://doi.org/10.1101/2021.11.19.469275; this version posted November 20, 2021. The copyright holder for this preprint (which was not certified by peer review) is the author/funder, who has granted bioRxiv a license to display the preprint in perpetuity. It is made available under aCC-BY-NC 4.0 International license.

123. Parichy, D. M. et al. An orthologue of the kit-related gene fms is required for development of neural crest-derived xanthophores and a subpopulation of adult melanocytes in the zebrafish , Danio rerio. Development 3044, 3031-3044 (2000).

124. Gross-Thebing, T., Paksa, A. \& Raz, E. Simultaneous high-resolution detection of multiple transcripts combined with localization of proteins in whole-mount embryos. BMC biology 12, 55 (2014).

125. Westerfield, M. A Guide for the Laboratory Use of Zebrafish Danio (Brachydanio) rerio. (University of Oregon Press, 2000). 